\title{
The correlation of Azerbaijan arid soils with WRB-2014
}

\section{Amin İsmayilov, Maharram Babaev, Fikrat Feyziyev*}

Institute of Soil Science and Agrochemistry of Azerbaijan National Academy of Science, AZ10073, Baku, Azerbaijan

\begin{abstract}
The geographical principles are used in grouping of the soils the highest taxonomic standards in the soviet soil scientists works concerning the classification. But the Azerbaijan soil classification is based on genetic profile. Traditionally - topographic, color, climate and so on names are used in this classification, which in the soils genetic types idea is assumed as a basis. The International classification system is identified on the basis of the diagnostic parameters in the field researches and specified as a result of the laboratory analyses. The Azerbaijan soil classification consists of eight taxonomic level and a high taxonomic level is considered- soil class, section, genetic soil type, low soil taxa - soil gender, sort, diversity, row, soil variants. Mainly used central taxon is soil type. An aim of the research is to determine correlative chances of WRB-2015 International soil classification system with the Azerbaijan soil classification. It was detected that a correlation of both soil classifications is possible. The correlation is taken place in different taxon levels. Therefore, the soils were analysed at a type and subtype standard besides high taxas when the soils were correlated. As a result of correlation, it was defined that irrigated meadow-grey soils should be correlated Anthrosols, but meadow-grey soils concerned Calcisols and Gleysols.
\end{abstract}

\section{Article Info}

Received : 21.11 .2019

Accepted : 11.04 .2020

Keywords: Correlation, WRB, Anthrosols, Calcisols, classification, meadow-grey soils.

(C) 2020 Federation of Eurasian Soil Science Societies. All rights reserved

\section{Introduction}

Soil classification is a means which have traditional and necessary importance in performing of the scientific and applied works in connection with the correct and expedient management of the soil productivity and registration of the soil resources. The soil classification is the form of defining soil diversities and also expanding of researches and modernization of soil reserves (Lebedeva et al., 2005; Sarmast et al., 2016). It is also an important instrument in the communication of soil research results at and international levels of soil science (Zádorová and Penížek, 2011; Rozhkov, 2012). Soil classifications are dynamic systems and their changes are closely related to the latitude of thought of soil researchers and the level of knowledge about soils. Yet soil classification principles should remain consistent with the geographical features of territory's evolution (Lebedeva and Gerasimova, 2009). There is a special soil researche program in every country some of them are fulfilled at an economical standard, some at state standard and some at national standard. Two approaches are available in soil classification establishment classification based on genetics and diagnostics (Bockheim and Gennadiyev, 2000). The first soil classification was established by the Russia soil scientists and built on genetic principles according to Dokuchaev's soil forming theory (Gerasimova, 2015).

Azerbaijan is one of such regions by its large specter of the horizontal and vertical soil zones more diversity of the lowest taxons and soil types. The modern soil regime processes are a basis of the Azerbaijan soil classification by paying attention to soil features and soil forming factors. The Azerbaijan soils classification was prepared by a genetic-profile principle. The classification taxa diagnostics on the basis of the soil profile structural characters is given by suggesting of the soils' division on genetic profile and this approach gives a chance to pay attention to all the natural and anthropogenic changed soils in the single soil classification.

\begin{tabular}{llll} 
Amin İsmayilov & $:$ & amin.ismayil@gmail.com \\
Maharram Babaev & $:$ & babayev.mp@gmail.com \\
Fikrat Feyziyev & $:$ & fikrat.fm@gmail.com \\
\hline
\end{tabular}

e-ISSN : $\quad 2147-4249$
$0000-0003-1878-415 X$

0000-0001-8337-1701

0000-0001-9771-9799
(Corresponding author) 
According to Salaev (1991), an ecological-genetic classification is more separated taxa system than other classification systems type- subtype-gender-sort. According to this approach the Azerbaijan soil map scaled as 1:100000 was prepared (1998) and adopted for the soil classification at a country's standard. As above mentioned, an available classification system of Azerbaijan soils is characterized regionally and its correlation to the International soil classification is necessary for participation in the integration process under the modern globalization condition. As it is known, WRB soil classification system $(F A 0,2015)$ is rather good for a national classification systems correlation, because the international correlation chances were taken into account while establishing this system, it is used for the middle and little scaled maps classification very much (Krasilinikov, 2009). There were efforts by several researchers in a correlation direction of the national soil classification based on genetic profile for the WRB. One of the main problems is the utilization of the different analysis methods for definition of the soil diagnostic indications and information shortage causes definite mistakes during correlation (Reintam and Koster, 2006; Urushadze et al., 2016). Though the Azerbaijan Soil Resources were investigated before the XX century, since 1945 they were begun to be studied in institutional form. Factually majority of the methods used in soil analyses is ancient and isn't used for WRB classification by International Union of Soil Sciences (IUSS). Though there is enough information about Azerbaijan soil resources for the local use, but its utilization in an international scale is difficult. It makes definite difficulty in integration to the International Soil Science. The differences and connections between the World Reference Base for Soil Resources and the Azerbaijan soil classification system were first summarized by Krasilnikov et al. (2009) who also established correlation keys primarily based on field experiences and the definitions of the classification units. However, they pointed out that the classes of the two systems cannot match due to their different approach and methodology. At present, the development of international cooperation in different sciences, including soil science, poses the problem of the creation of a new soil classification system that should be based not only on the regional and national classification concepts but also linked with the internationally accepted soil classification systems (Babaev et al., 2006; Gerasimova, 2015). An increasing demand for harmonized digital soil information can be observed nowadays. The correlation of national systems with WRB has got a new priority, as it is necessary for the development of European and global databases, giving the opportunity to enrich them with more new data (Kabała et al., 2015). The former Soviet countries mainly used form the classification grounded on genetic profile (Shishov, 2004), last years the correlation process is performing for the WRB international classification system. In this direction the expert based, concept based and centroid based methods are mostly used, these methods effectively help the correlation process (Lang, 2013). The research aim is to investigate a correlation of the Azerbaijan soil classification to the WRB soil classification and to define their different and unlike characters. As a research object the meadow grey, irrigated meadow-grey soils which are dominant soil type for the Azerbaijan zone have been taken.

\section{Material and Methods}

The study area was Mugan plain, located the central part of Kur-Araks lowland between $39^{\circ} 43^{\prime} 18^{\prime \prime} \mathrm{N}$ and $39^{\circ} 44^{\prime} 40^{\prime \prime} \mathrm{N}$ latitude and $47^{\circ} 58^{\prime} 14^{\prime \prime}$ and $48^{\circ} 57^{\prime} 32 \mathrm{E}$ longitude covering an area of $4500 \mathrm{~km}^{2}$. It has an arid climatic condition and a quantity of the rainfalls is $180-250 \mathrm{~mm}$. Evaporation is between $800-1000 \mathrm{~mm}$. Annual average temperature changed between 14-15 $\mathrm{o}$. The arid sone of Azerbaijan characterized with its agrarian importance and soils mainly used under different agricultural plants such as wheat, barley, cotton, lucerne and vegetables. The main part of research area is located under sea level for this reason soils genetically have high risk to salinization. The elevation of the main part of the research area is located under sea level and changed between -37-50 m. Most of the current topography is a result of post-glacial processes during the quaternary period. The low elevation areas are mainly covered by alluvial, marine and lacustrine materials.

The WRB-2014 (2015 update) criteria which were adopted by the world soil scientists were assumed as a basis. While investigating the correlation opportunities the method (Minasny et al., 2010) based on conception and Krasilnikov et al. (2009) approaches were used. The last version of the Azerbaijan soil classification was in 2011 (Babaev et al., 2011) and the main taxa were determined.

45 soil pedons were excavated in the research area. The main soil types are meadow-grey and irrigated meadow-grey soils. On field checks, the geographical positions of representative soils for each site were determined by Global Positioning System. The soil profiles were excavated and described according to the "Guidelines for soil description" (FAO, 2006). Soil samples from different genetic horizons were taken, and samples were air dried, crushed, and passed through a $2 \mathrm{~mm}$ sieve. Pipette method was used for texture analysis (Gee and Bauder, 1986), Organic matter by Walkley-Black method (Walkley and Black, 1934), 
calcium carbonate by calcimetric method (Loeppert and Suarez, 1996), cation exchange capacity by was defined as sum of exchangeable cations (Bower and Hatcher, 1966), pH and EC by pH-meter and EC-meter.
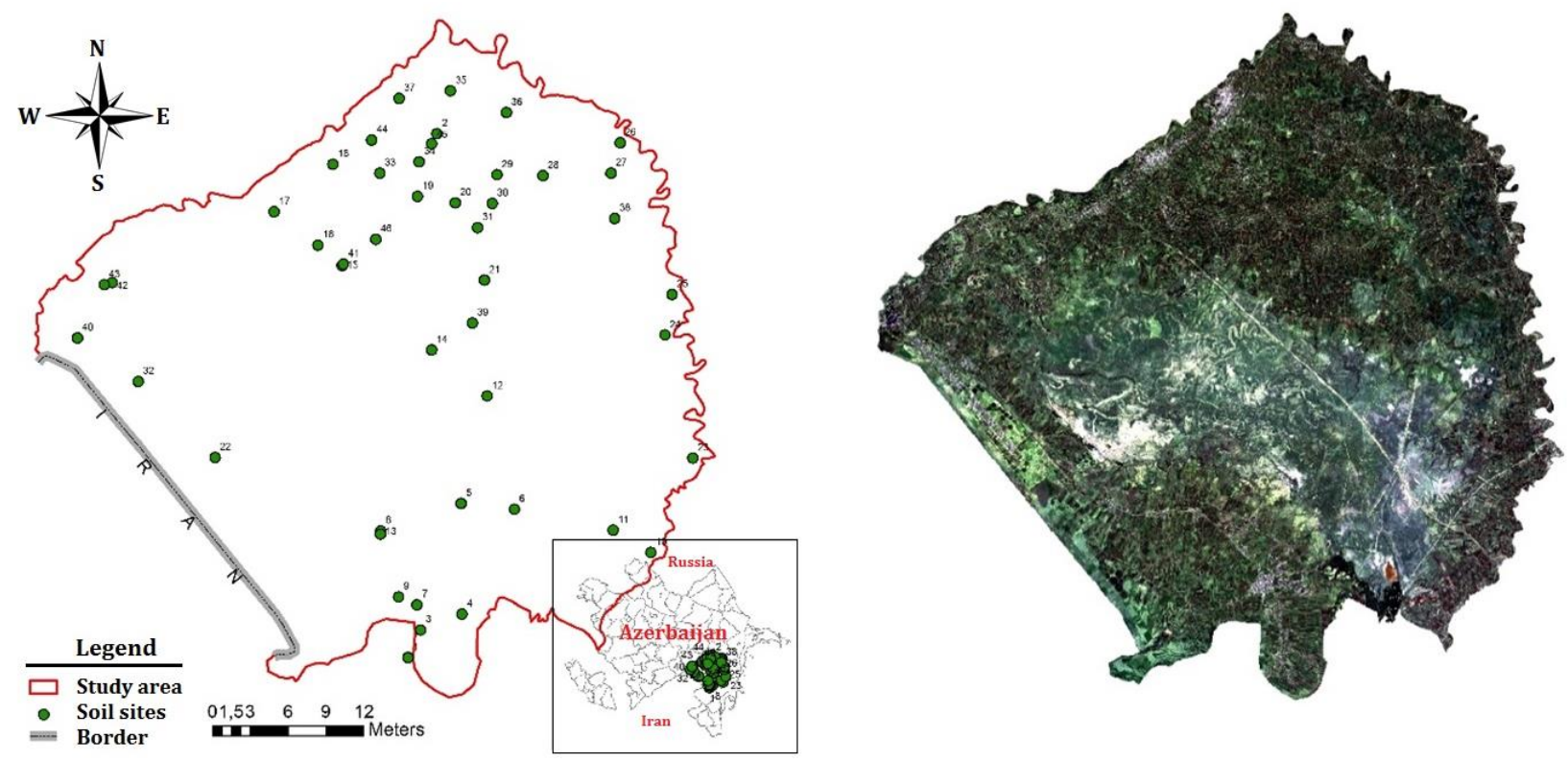

Figure 1. Study area (soil pedon distribution and natural color composition)

A last version of the Azerbaijan soil classification was printed in 2011 (Babaev et al., 2011). The Azerbaijan soil classification consists of 3 classes, 15 sections, 37 types, 90 subtypes, 146 genders, (species); 388 sorts, 140 diversities, 157 rows, 47 variants. This variety forms large information about the soils and simplifies correlation opportunities. The soil passports (over the types) prepared according to the Azerbaijan soil classification rules and Azerbaijan Soil Map with the scale of 1:100000 were used. Soils were classified according to the WRB (FAO, 2015) soil classification systems. Finally, the soil units of WRB were compared with Azerbaijan soil classification based on genetic properties.

\section{Results and Discussion}

The irrigated meadow-grey, meadow-grey soil types which are dominant for the Azerbaijan arid soil zone were taken in order to investigate the correlation opportunities to the WRB soil classification. Azerbaijan soil classification were correlated the at a type level and determined the principal soil types paying attention to the main soil forming character concerning the WRB 2006 version (Babaev, 2018). This process has not realized in the low taxa. However, one soil type concerns 2 Soil Reference Group (RSG) in the WRB in some cases. On the other hand, the small taxa which are taken as a diagnostic indication in the Azerbaijan soil classification aren't characteristic for the WRB RSG in some cases. Therefore, using of more information is rather important while performing the WRB correlation process. The Azerbaijan soil classification is hierarchic structural. The greatest taxon is considered soil class, the smallest taxon is considered a variant. In general the Azerbaijan classification involves two units system. A high taxonomic level-soil class, section, genetic soil type. The low soil taxons-soil gender, sort, diversity, row, soil variants paying attention to the soil fruitfulness ability. Prior to elaboration of the new Azerbaijan soil classification system a complete systematized list of soils was compiled on the basis of the explication to the soil map of Azerbaijan on a scale of 1:100000, which characterizes in detail the spatial distribution of different genetic soil groups (Babayev et al., 2006). Correlation of the meadow-grey and irrigated meadow-grey soils to the WRB was identified as Calcisols in the first initiative performed according to the archive materials. A main diagnostic indication in definition of these soils as an independent soil type is a sign of the oxidation-reduction process which is formed by subsoil water in the location depth and soil profile. Meadow-grey soil type developed under the winter pastures in the plain zones. The soil profile thickness is $>120 \mathrm{~cm}$. There are two subtypes. The ground waters in the meadow-grey subtype are situated below $200 \mathrm{~cm}$ and oxidation- reduction processes mainly occur B and C horizons (Babayev, 1984).

Gleying is observed beginning of B layer in the profile as a result of the ground waterseasonal fluctuation in the meadow-grey soils. The soil profile is calcareous and an average quantity of carbonates is $10,8 \%$. As a result of the high evaporation $\mathrm{CaCO}_{3}$ or gypsum accumulation on the upper layers is characterized by the ground waters. The quantity of carbonates on the topsoil changed between 3.8-141.7 g/ $\mathrm{kg}$ and mean values is $103.3 \mathrm{~g} / \mathrm{kg}$. But within the profile the value of carbonates increased $(46.7-215.8 \mathrm{~g} / \mathrm{kg}$ ). A quantity of organic substances changes by $1,5-3 \%, \mathrm{pH}-8-9$. On the other hand, salinized-solonetzificated process is 
characteristic for the soil profile and the dissolved salts are accumulated at $50 \mathrm{~cm}$ of depth. These soils correlate to Haplic Calcisols (Gleyic, Salic). These soils spread in an associated form with the saline soils. A main characteristic feature of the Calcisols is accumulation of secondary carbonates in the soil profile. Oxidation-reduction process indications which are created under the groundwater effect are taken into account at a second level. Though this process was clearly given in the national classification, it was distinguished in the gender and sort taxa. The main morphological characteristics of characteristic pedons were given in Table 1. A main characteristic feature in the irrigated meadow-grey soil type is Irragric horizon formation as a result of the long irrigation and cultivation. The irrigated meadow-gray soils of the study area have been formed on the Araks river basin. These soils are irrigated by the channels separated from Araks River. Araks river has high content of mineral and nutritional content. The mineralization of irrigation water is 560-880 mg/l. Morphological and diagnostic indicators of soil have changed considerably as a result of irrigation of cultivated areas using these waters.
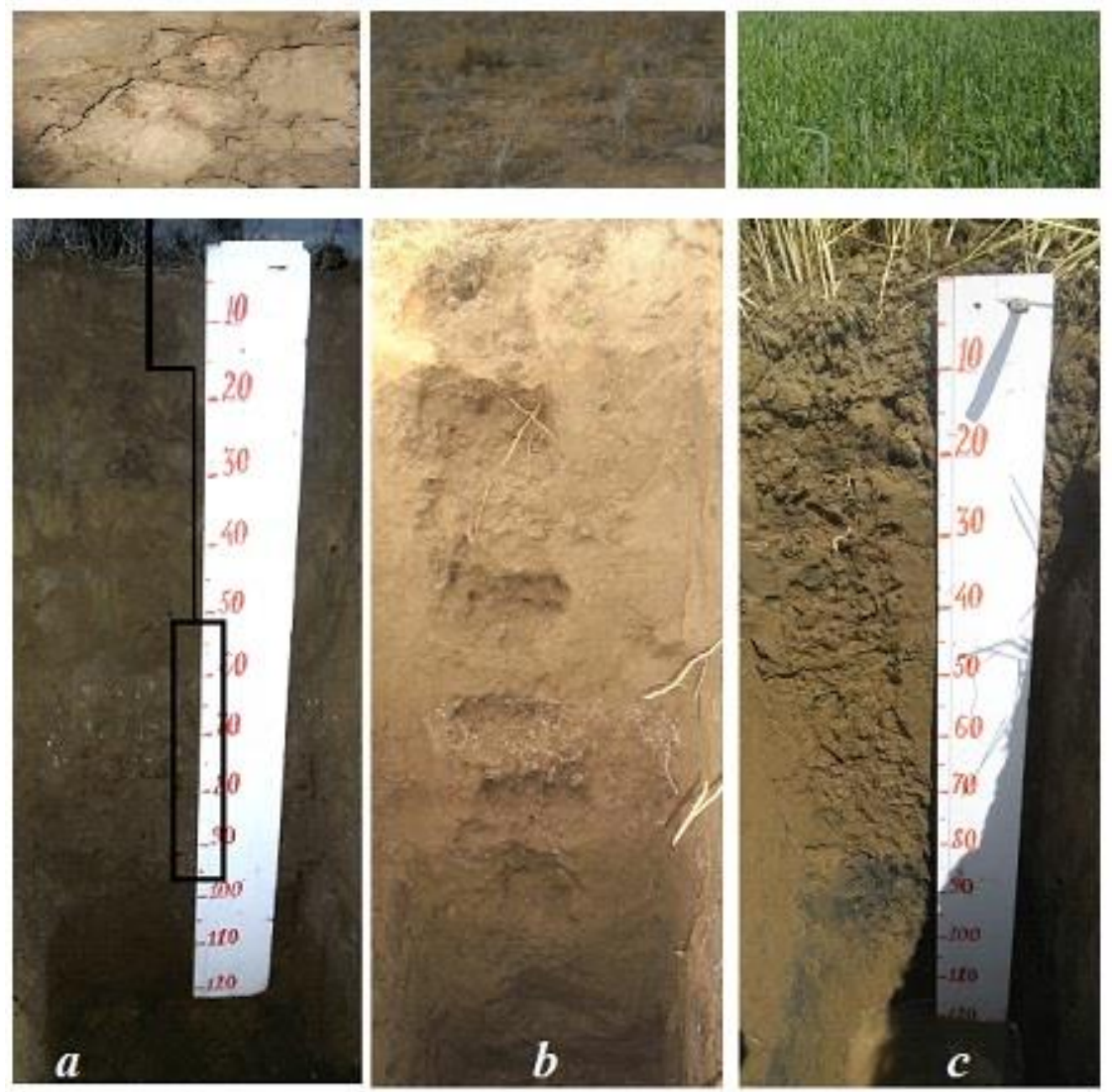

Figure 2. Gleysols (a), Calcisols (c) and Anthrosols (c) of Mugan lowland

The main reason of formation of pedodiversity on the type level is the changing of soil formation processes. In this case, it forms the changes in soil taxa and the current taxon's isn't enough to describe soil classification systems in global way (Bockheim and Gennadiyev, 2000).

In any case, guarding of the natural structure is impossible, because majority of the soil is under anthropogenic impact to some or other degree. Babaev (1984) consolidated such soils in the highest taxa anthropogenic changed soils class paying attention to the long anthropogenic, especially irrigation impact. The agroirrigation horizon was formed in the soil profile by the impact of the long irrigation and cultivation in morphogenetic diagnostics of these soils. Thickness of this layer is more than $50 \mathrm{~cm}$. The soil profile became dark, humus was washed into the deep layers. The burial state exists in these soils (Figure 2). Correlation of this soil type to the WRB confirms with the Anthrosols RSG and the Irragric Anthrosols (Gleyic, Loamic) soils were formed. As is seen the correlation to the WRB occurs in the highest taxon-class level in this soil type. 
Table 1. Morphological characteristics of studied pedons

\begin{tabular}{|c|c|c|c|c|c|c|c|c|c|}
\hline \multirow{2}{*}{$\begin{array}{l}\text { Profile } \\
\text { No and } \\
\text { cordinates }\end{array}$} & \multirow[b]{2}{*}{ 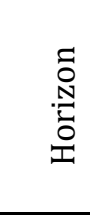 } & \multirow[b]{2}{*}{ } & \multirow{2}{*}{ 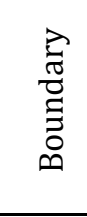 } & \multicolumn{2}{|c|}{ Colour } & \multirow{2}{*}{ 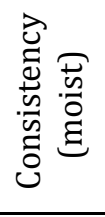 } & \multirow{2}{*}{ 节 } & \multirow{2}{*}{ 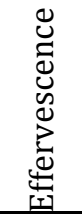 } & \multirow{2}{*}{ 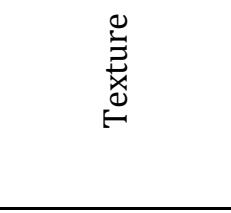 } \\
\hline & & & & Moist & Dry & & & & \\
\hline S13 & Ap & $0-16$ & GS & $10 Y R 4 / 3$ & 10YR7/1 & LO & GR & MO & Silty-clay \\
\hline $39 \div 33^{\prime} 02 \mathrm{~N}$ & A1 & $16-30$ & GS & 10YR4/2 & 10YR7/4 & FR & $\mathrm{AB}$ & $\mathrm{ST}$ & Silty-clay \\
\hline \multirow[t]{3}{*}{$48^{\circ} 36^{\prime} 36 \mathrm{E}$} & $\mathrm{ABc}$ & $30-58$ & GS & 10YR5/4 & 10YR7/4 & VFR & MA & MO & Silty-clay \\
\hline & $\mathrm{Bk}$ & $58-92$ & $\mathrm{CS}$ & 10YR4/4 & 10YR7/3 & VFR & MA & $\mathrm{ST}$ & Clay \\
\hline & $\mathrm{CBz}$ & $92-124$ & $\mathrm{CS}$ & 10YR5/3 & 10YR7/2 & VFR & $\mathrm{BL}$ & ST & Clay \\
\hline S16 & Ap & $0-18$ & GW & 10YR5/3 & 10YR6/4 & FR & $\mathrm{SG}$ & ST & Silty-clay \\
\hline $39 \div 26$ '28 N & A1 & $18-33$ & GS & 10YR5/3 & 10YR6/2 & FR & $\mathrm{SA}$ & ST & Silty-clay \\
\hline \multirow[t]{3}{*}{$48^{\circ} 31^{\prime} 16 \mathrm{E}$} & $\mathrm{AB}$ & $33-57$ & $\mathrm{CS}$ & 10YR4/2 & 10YR7/3 & FR & $\mathrm{SA}$ & $\mathrm{ST}$ & Silty-clay \\
\hline & $\mathrm{Bg}$ & $57-94$ & AS & 10YR5/3 & 10YR6/3 & FR & AS & ST & Silty-clay \\
\hline & $\mathrm{Cr}$ & 94-132 & AS & $10 Y R 5 / 3$ & 10YR7/2 & FR & AS & ST & Silty-clay \\
\hline \multirow{5}{*}{$\begin{array}{l}\text { S19 } \\
39040 ' 30 \\
48 \div 38 \text { '41 E }\end{array}$} & $\mathrm{A}$ & $0-8$ & $\mathrm{CS}$ & 10YR3/2 & 10YR5/2 & VFR & MA & ST & Clay-loam \\
\hline & A1 & $8-26$ & $\mathrm{CS}$ & 10YR3/2 & 10YR6/2 & VFR & $\mathrm{SN}$ & ST & Silty-clay-loam \\
\hline & $\mathrm{Bc}$ & $26-49$ & $\mathrm{CS}$ & 10YR6/4 & 10YR7/1 & FR & $\mathrm{SA}$ & ST & Silty-loam \\
\hline & $\mathrm{BCc}$ & $49-78$ & $\mathrm{CS}$ & 10YR5/4 & 10YR8/1 & FR & AS & ST & Silty-loam \\
\hline & $\mathrm{Cg}$ & 78-109 & $\mathrm{CS}$ & 10YR5/3 & 10YR8/2 & FR & AS & ST & Silty-loam \\
\hline \multirow{5}{*}{$\begin{array}{l}\text { S20 } \\
39043^{\prime} 35 \mathrm{~N} \\
48^{\circ} 33^{\prime} 37 \mathrm{E}\end{array}$} & $\mathrm{A}$ & $0-9$ & $\mathrm{CS}$ & 10YR3/2 & 10YR6/3 & FR & $\mathrm{AB}$ & ST & Silty-loam \\
\hline & $\mathrm{AB}$ & $9-30$ & $\mathrm{CS}$ & 10YR6/4 & 10YR8/3 & FR & $\mathrm{SB}$ & ST & Silty-loam \\
\hline & $\mathrm{Bg}$ & $30-58$ & $\mathrm{CS}$ & 10YR6/5 & 10YR7/4 & MFR & $\mathrm{M}$ & ST & Silty-clay-loam \\
\hline & $\mathrm{BCg}$ & $58-89$ & $\mathrm{CS}$ & 10YR5/5 & 10YR7/3 & SH & M & ST & Silty-clay \\
\hline & $\mathrm{Cg}$ & 89-118 & $\mathrm{CS}$ & $10 \mathrm{YR} 4 / 3$ & 10YR6/3 & $\mathrm{SH}$ & $\mathrm{M}$ & ST & Silty \\
\hline \multirow{4}{*}{$\begin{array}{l}\text { S31 } \\
39036 \text { '34 N } \\
48 \div 57^{\prime} 11 \mathrm{E}\end{array}$} & Ap & $0-23$ & GW & 10YR6/2 & 10YR8/2 & VFR & $\mathrm{SG}$ & ST & Silty-clay-loam \\
\hline & A1 & $23-49$ & GS & 10YR5/4 & 10YR7/2 & FR & $\mathrm{SB}$ & ST & Silty-clay-loam \\
\hline & $\mathrm{Bk}$ & $49-81$ & $\mathrm{CS}$ & 10YR5/2 & 10YR7/3 & FR & $\mathrm{SB}$ & $\mathrm{ST}$ & Silty-clay-loam \\
\hline & $\mathrm{BCk}$ & $81-114$ & $\mathrm{CS}$ & 10YR7/4 & 10YR8/2 & MFR & SB & ST & Silty-clay-loam \\
\hline \multirow{5}{*}{$\begin{array}{l}\text { S35 } \\
39 \circ 56^{\prime} 60 \mathrm{~N} \\
48^{\circ} 49^{\prime} 22 \mathrm{E}\end{array}$} & Ap & $0-20$ & GW & $10 Y R 4 / 3$ & 10YR6/3 & FR & GR & ST & Silty-clay-loam \\
\hline & A1 & $20-30$ & GS & 10YR4/2 & 10YR6/2 & FR & AS & ST & Loam \\
\hline & $\mathrm{AB}$ & $30-74$ & GS & 10YR5/3 & 10YR7/3 & VFR & AS & ST & Silty-clay-loam \\
\hline & $\mathrm{Bg}$ & $74-88$ & $\mathrm{CS}$ & 10YR4/1 & 10YR7/1 & VFR & $\mathrm{SA}$ & ST & Silty-clay-loam \\
\hline & $\mathrm{Cg}$ & $88-126$ & $\mathrm{CS}$ & 10YR6/3 & 10YR8/4 & VFR & $\mathrm{SB}$ & ST & Silty-clay-loam \\
\hline \multirow{5}{*}{$\begin{array}{l}\text { S41 } \\
39049^{\prime} 20 \mathrm{~N} \\
48^{\circ}-25^{\prime} 30 \mathrm{E}\end{array}$} & Ap & $0-26$ & GS & 10YR4/3 & 10YR8/3 & FI & GR & ST & Silty-clay-loam \\
\hline & A1 & $26-48$ & GS & 10YR4/4 & 10YR7/3 & $\mathrm{FR}$ & $\mathrm{AB}$ & $\mathrm{ST}$ & Silty-clay-loam \\
\hline & $\mathrm{ABk}$ & $48-76$ & $\mathrm{CS}$ & 10YR5/4 & 10YR7/3 & FR & SA & ST & Silt-loam \\
\hline & $\mathrm{Bg}$ & $76-99$ & $\mathrm{CS}$ & 10YR4/3 & 10YR7/4 & $\mathrm{FR}$ & MA & $\mathrm{ST}$ & Silty-clay-loam \\
\hline & $\mathrm{BCg}$ & $99-138$ & $\mathrm{CS}$ & 10YR4/4 & 10YR8/4 & FR & MA & ST & Silt-loam \\
\hline
\end{tabular}

Boundary: distinctness (A-abrupt, C-clear, G-gradual); topography (S - smooth, W - wavy). Consistency: moist (L- loose, VFR - very friable, FR- friable, FI- firm, VFI-very firm). Structure: type (AS-angular and subangular block, AB - angular blocky, SB - subangular blocky, SG-single grain, SA- subangular and angular blocy MA - massive). Effervescence: class (ST - strongly effervescent, MOmoderately).

\section{Conclusion}

The Azerbaijan soil classification is called according to morphology, colour, climate, topographic and so on and the chemical parameters are characterized diagnostically. Some of the small taxa aren't used in correlation. For example, the differentiation isn't performed in WRB for the soil profile density and cultured level which include in the small taxon-row and variant. The results showed that the correlation of the low taxa gender, sort and diversity used in the national soil classification to the WRB is possible. The Azerbaijan soil classification correlation based on genetic profile can be occurred at different levels. Sometimes correlation to the WRB does not result positively at a type level and it can conform to the separate Soil Reference Group at the subtypes level that includes in the type. The soil formation direction is assumed a basis while the soil types are divided into subtypes in the Azerbaijan soil classification in any case. Therefore, the correlation is also observed at a subtype level. The smallest taxa conform to the main and additional qualifications. It is possible to correlate the Azerbaijan soil classification based on genetic profile to the WRB at a different taxon level paying attention to an analogy of the soil forming process. But there is a great need for high perceptibility and expert discussion in this problem. While establishing the Azerbaijan soil classification a great scaled map is assumed as a base map and it is mainly local applied characteristic. 


\section{References}

Babaev, M.P., 1984. Irrigated soils of the Kura-Araks lowland and their productive capacity. Elm. Baku, Azerbaijan. 176p. [in Russian].

Babaev, M.P., Dzhafarova, Ch.M., Gasanov, V.G., 2006. Modern Azerbaijani soil classification system. Eurasian Soil Science 39(11): 1176-1182.

Babaev, M.P., İsmayilov, A.İ, Huseynova, S.M., 2017. The correlation of Azerbaijan national soil classification with WRB. Elm. Baku, Azerbaijan. 271p.

Babaev, M.P., Jafarova, Ch.M., Hasanov, V., 2006. Modern classification of Azerbaijan soils. Elm. Baku, Azerbaijan. 360p.

Bockheim, J.G., Gennadiyev, A.N., 2000. The role of soil-forming processes in the definition of taxa in Soil Taxonomy and the World Soil Reference Base. Geoderma 95(1-2): 53-72.

Bower, C.A., Hatcher, J.T., 1966. Simultaneous determination of surface area and cation exchange capacity. Soil Science Society America Journal 30(4): 525-527.

FA0, 2006. Guidelines for soil description. Fourth edition. FAO. Food and Agriculture Organization of the United Nations, Rome, Italy. 97p. Available at [Access date: 21.11.2019]: http://www.fao.org/3/a-a0541e.pdf

FA0, 2015. World reference base for soil resources 2014. International soil classification system for naming soils and creating legends for soil maps. Update 2015. World Soil Resources Reports No. 106. Food and Agriculture Organization of the United Nations, Rome, Italy. 192p. Available at [Access date: 21.11.2019]: http://www.fao.org/3/i3794en/I3794en.pdf

Gee, G.W., Bauder, J.W., 1986. Particle-size Analysis. In: Methods of Soil Analysis, Part 2, Chemical and Microbiological Properties, A.L. Page, R.H. Miller, D.R. Keeney (Eds.), 2nd Edition. Agronomy Monograph No. 9, American Society of Agronomy, Soil Science Society of America. Madison, Wisconsin, USA. pp. 383-411.

Gerasimova, M.I., 2015. Principles, structure and taxonomic units in the Russian and International (WRB) systems of soil classification. Bulletin of the V.V. Dokuchaev Soil Science Institute 79: 15-25.

Kabała, C., Świtoniak, M., Charzyński, P., 2016. Correlation between the Polish Soil Classification (2011) and international soil classification system World Reference Base for Soil Resources (2015). Soil Science Annual 67(2): 88-100.

Krasilnikov, P., Marti, J.J.I., Arnold, R., Shoba, S., 2009. A handbook of soil terminology, correlation and classification. Taylor \& Francis Ltd, London, UK. 448p.

Láng, V., Fuchs, M., Waltner, I., Michéli, E. 2013. Soil taxonomic distance, a tool for correlation: As exemplified by the Hungarian Brown Forest Soils and related WRB Reference Soil Groups. Geoderma 192: 269-276.

Lebedeva, I.I., Gerasimova, M.I., 2009. M.I. Factors of soil formation in soil classification systems. Eurasian Soil Science 42: 1412-1415.

Lebedeva, I.I., Tonkonogov, V.D., Gerasimova, M.I., 2005. Anthropogenic pedogenesis and the new classification system of Russian soils. Eurasian Soil Science 38(10): 1026-1031.

Loeppert, R.H., Suarez, D.L., 1996. Carbonate and gypsum. In: Methods of Soil Analysis, Part 3 - Chemical Methods. Sparks, D.L., Page, A.L., Helmke, P.A., Loeppert, R.H., Soltanpour, P.N., Tabatabai, M.A., Johnston, C.T., Sumner, M.E. (Eds.). American Society of Agronomy Inc., Madison, Wisconsin, USA. pp. 437-475.

Minasny, B., McBratney, A.B., Hartemink, A.E., 2010. Global pedodiversity, taxonomic distance, and the World Reference Base. Geoderma 155(3-4): 132-139.

Reintam, E., Köster, T., 2006. The role of chemical indicators to correlate some Estonian soils with WRB and Soil Taxonomy criteria. Geoderma 136(1-2): 199-209.

Rozhkov, V.A., 2012. Classiology and soil classification. Eurasian Soil Science 45: 221-230.

Salaev, M.E., 1991. Diagnosis and classification of soils of Azerbaijan. Elm. Baku, Azerbaijan [in Russian].

Sarmast, M., Farpoor, M.H., Boroujeni, I.E., 2016. Comparing Soil Taxonomy (2014) and updated WRB (2015) for describing calcareous and gypsiferous soils, Central Iran. Catena 145: 83-91.

Shishov, L.L., Tonkonogov, V.D., Lebedeva, I.I., Gerasimova, M.I., 2004. Classification and diagnostics of soils of Russia. Oykumena, Smolensk. 342p. [in Russian].

Urushadze, T., Blum, W., Kvrivishvili, T., 2016. Classification of soils on sediments, sedimentary and andesitic rocks in Georgia by the WRB system. Annals of Agrarian Science 14(4): 351-355.

Walkley, A.J., Black, I.A., 1934. Estimation of soil organic carbon by the chromic acid titration method. Soil Science 37(1): 29-38.

Zádorová, T., Penížek, V., 2011. Problems in correlation of Czech national soil classification and World Reference Base 2006. Geoderma 167-168: 54-60. 